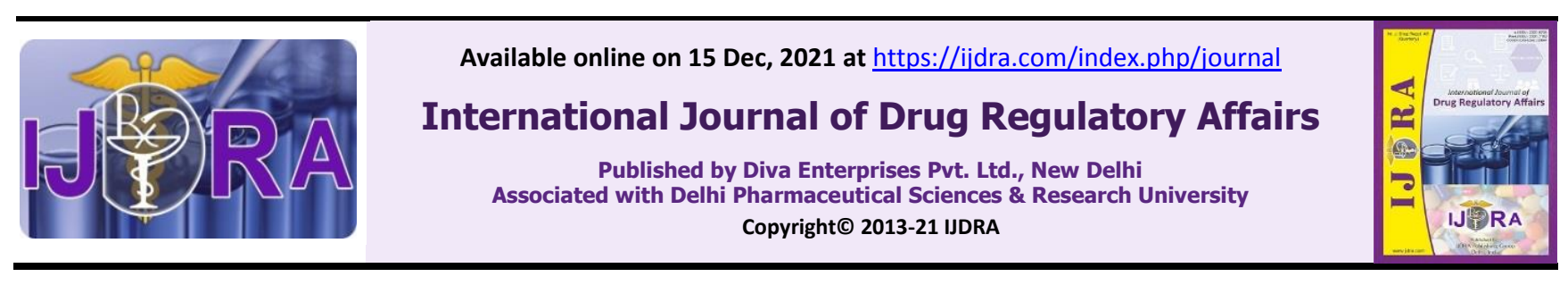

Review Article

Open $\odot$ Access

\title{
Current Regulatory requirements for registration of nutraceuticals in ASEAN
}

\author{
Jitendra Kumar Badjatya ${ }^{\text {a }}$ Pooja Chaudhari *,b \\ ${ }^{a}$ Regulatory Affairs Professional \& Editor-IJDRA Journal, Delhi, India \\ ${ }^{b}$ Regulatory Affairs Professional, Nandan Villa, Near Patidar Bhavan, Vaidya Nagar, Nashik, India
}

\begin{abstract}
Nutraceuticals are bioactive or natural chemical components that are been marketed all over the world. It claims to be disease preventing along with health promoting product with some of the medicinal properties. It is categorized as vitamin, mineral, animal product and health supplement. Nutraceuticals has the major advantage over the medicines as they avoid the adverse effects that are caused by drugs. Nutraceutical market is expanding day by day and the claim for the product is enlarging. Users are looking for alternatives for the prescribed medicines as well as the health product that will supplement dietary intake on daily basis. Different countries classified products into various categories depending upon their health claim. In Association of South East Asian Nations (ASEAN) the Asian Alliance of Health Supplement Association (AAHSA) regulates the responsibilities to ensure that the nutraceuticals before marketing are safe.
\end{abstract}

Keywords: ASEAN, Asian Alliance of Health Supplement Association (AAHSA), nutraceuticals, health supplements.

Article Info: Received 09 Nov. 2021; Review Completed 11 Dec. 2021; Accepted 15 Dec. 2021

\section{Cite this article as:}

Badjatya JK, Chaudhari P. Current Regulatory requirements for registration of nutraceuticals in ASEAN. Int J Drug Reg Affairs [Internet]. 2021 Dec 15 [cited 2021 Dec 15]; 9(3):37-45. Available from:

http://ijdra.com/index.php/journal/article/view/501

DOI: 10.22270/ijdra.v9i4.501

*Corresponding author

\section{Introduction}

In modern years, a new prototype of diet health is emerging. The new lifestyle adopted these days has changed the basic habits of food. Utilization of junk food is increasing day by day leading to a number of various diseases, occurred due to improper nutrition. Principal cause of most of the death in various country is heart disease followed by cancer, arthritis etc. consumers are approaching to the alternative beneficial product.

Nutraceutical was termed from "Nutrition" and "Pharmaceutical". Nutraceutical are the food or part of food that has health benefits including the prevention and treatment of various diseases, improving health, delaying the aging process or increasing life expectancy. Concept of nutraceutical arose where diet was higher rated by consumers then exercise in order to achieve good health.

It includes vitamins, minerals, herbs and other botanical amino acid, dietary substances, essential oils, natural substance of plant and animal origin as a supplementary diet for human use. These nutritional supplements are limited to the products which are to be administered orally in the form of tablet, capsule, granules, powder, liquid or soft gels. (1-3)

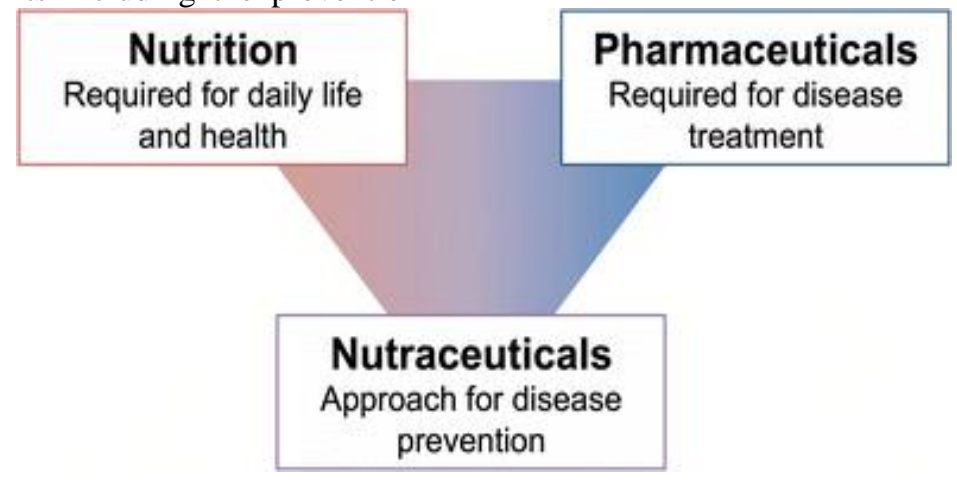

Figure 1. Fundamental role of nutraceutical 


\section{Classification of nutraceuticals}

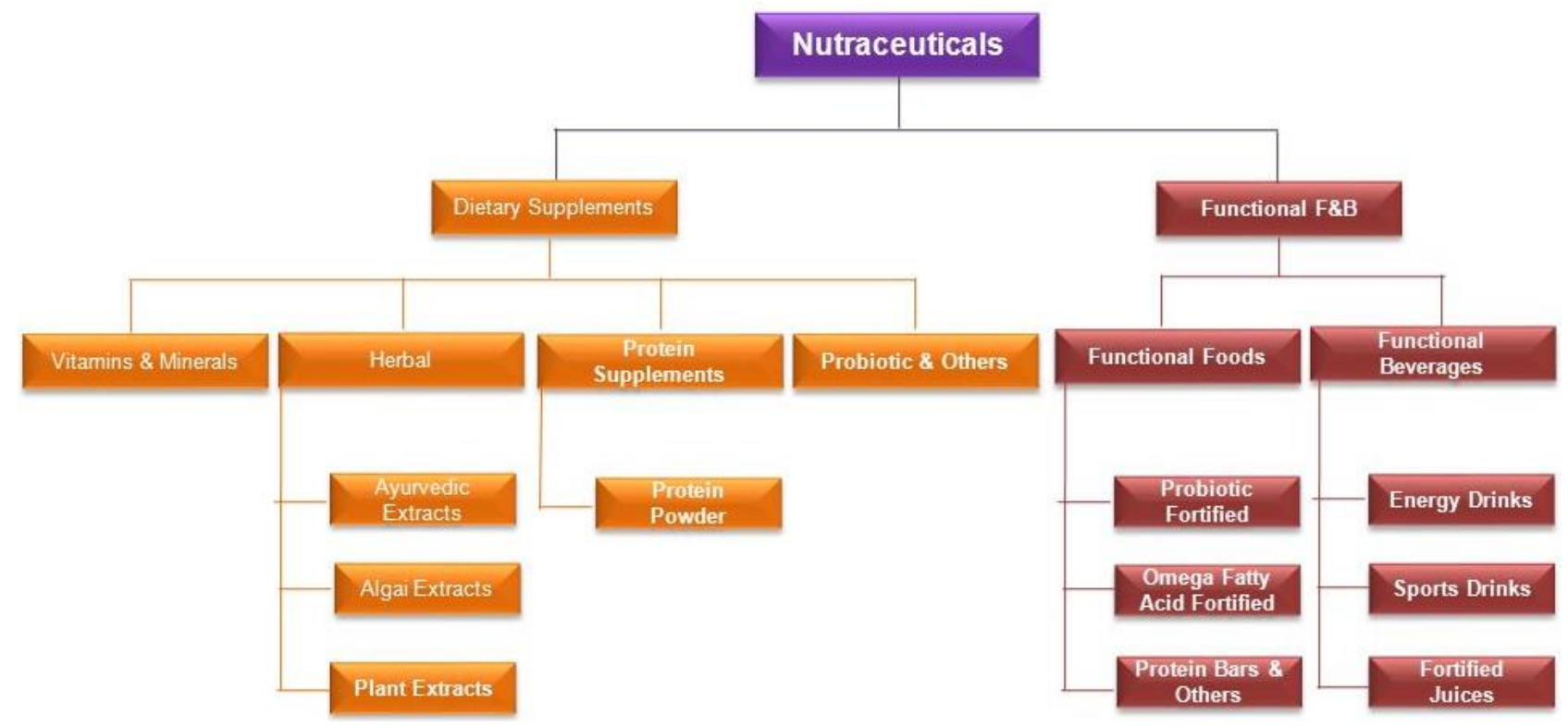

Figure 2. Classification of Nutraceuticals.

Nutraceutical ingredients market can also be further classified as:

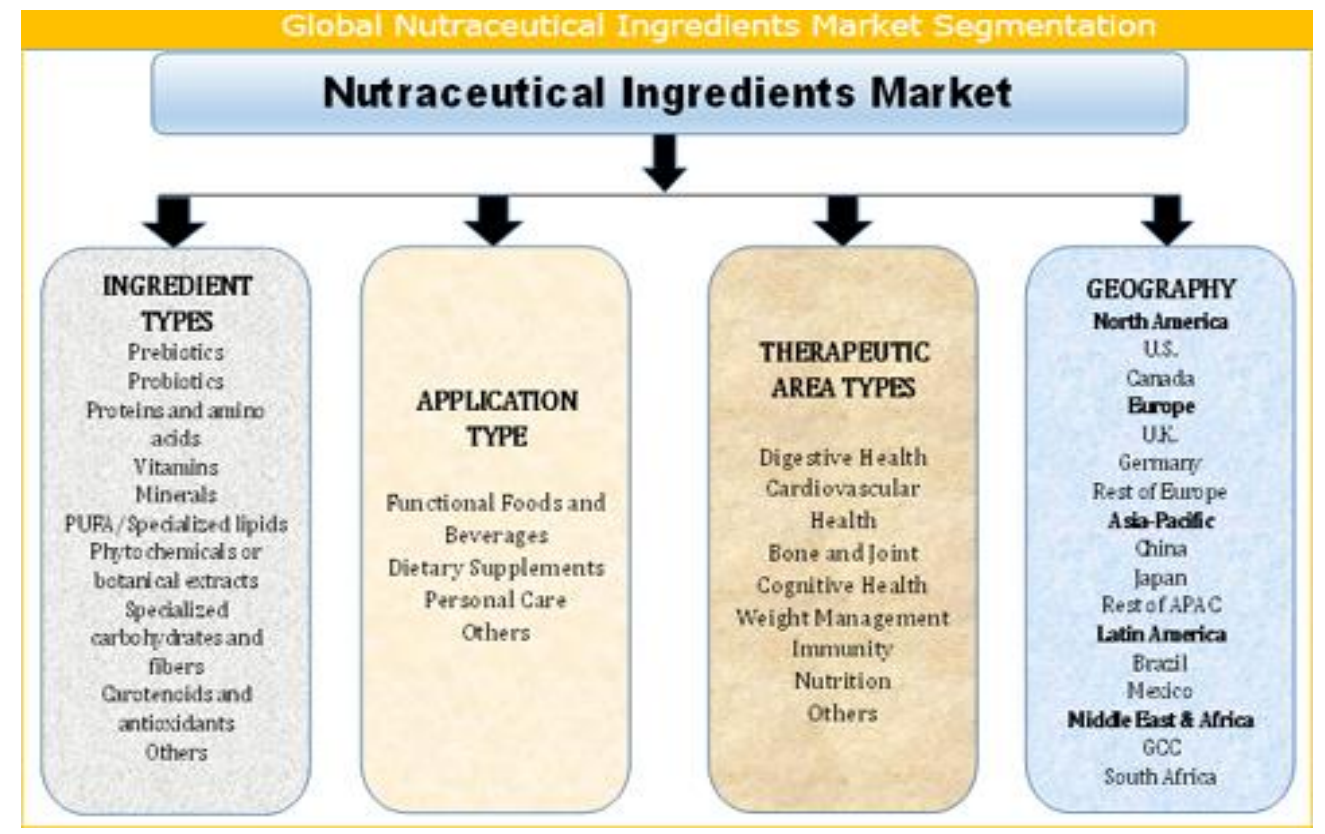

Figure 3. Classification of nutraceutical ingredient market

\section{Nutraceuticals in ASEAN countries (4-8)}

The Association of Southeast Asian Nations (ASEAN) came into existence on $8^{\text {th }}$ of August 1967. Member countries within ASEAN region are Myanmar, Cambodia, Indonesia, Brunei Darussalam, Lao PDR, Philippines, Thailand, Singapore, Malaysia, Vietnam and Singapore.

The terms Food Supplements, Dietary Supplements and Health Supplements are used to refer to the category in ASEAN. Amongst the ASEAN countries, "Food Supplements" term is used by 3 countries Indonesia, Philippines, and Vietnam. "Dietary Supplement" term is used is used by 3 countries Myanmar, Philippines and Thailand. While "Health Supplements" term is used by 4 countries Brunei Darussalam, Cambodia, Malaysia and Singapore. Currently each ASEAN member have distinct standards and requirements health supplement level and ingredients.

ASEAN Alliance of Health Supplement Association (AAHSA) represents the health supplements industry in the member countries. It includes 7 National level Health Supplement Association-
i. Indonesia- Association Pengusaha Suplemen Kesehatan Indonesia.
ii. Philippines- Health and Dietary Supplements Association of Philippines.
iii. Vietnam- Vietnam Association of Functional Foods.


iv. Thailand- Health Food and Supplement Association.

v. Brunei Darussalam- Health and Cosmetic Association.

vi. Malaysia- Malaysian Dietary Supplements Association. vii. Singapore- Health Supplements Industry Association of Singapore.

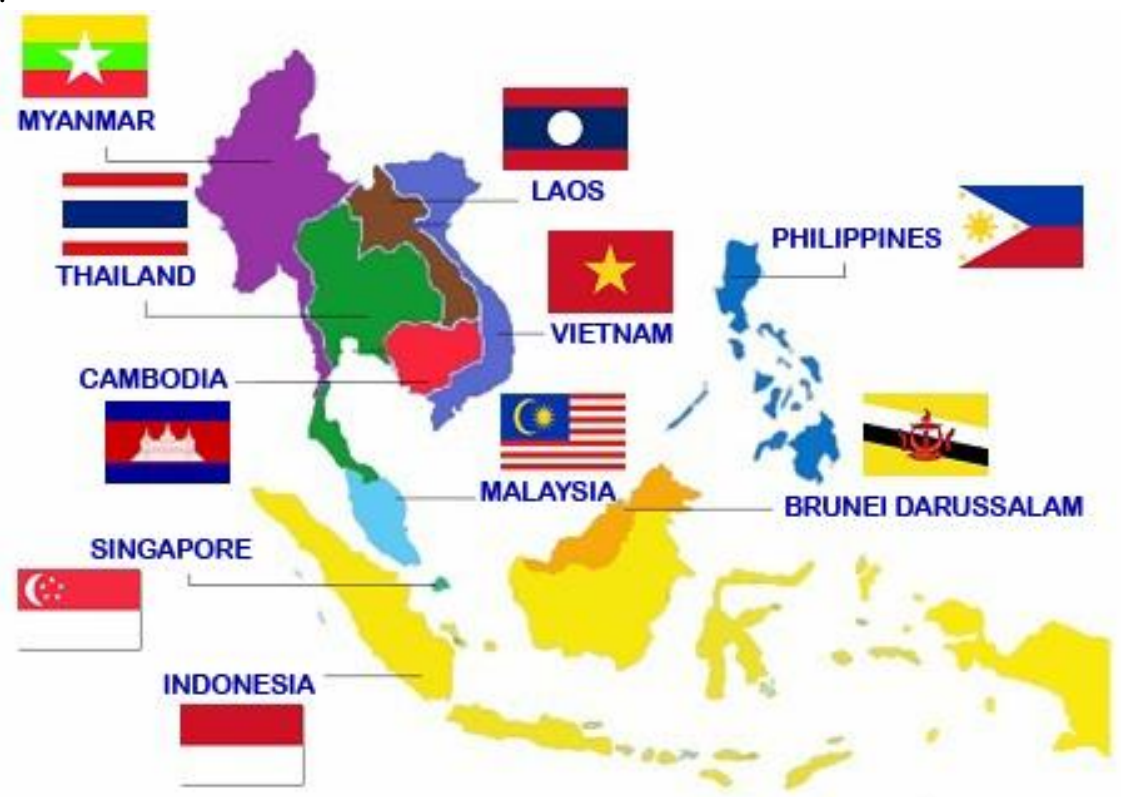

Figure 4. Map of member countries in ASEAN

A Health Supplement is defined as any product that is used as diet supplement as well as to maintain or upgrade or strengthen the healthy function of the human body. It may contain one or more than one combinations of mentioned below-

a) Vitamins, minerals, fatty acids, amino acid, enzymes, bioactive substance or probiotic.

b) Natural sources derived including mineral, animal and plant materials in the form of metabolites, extracts or concentrates. c) Synthetic sources of ingredients listed in aor b can only be used if safety has been proven.

It is presented in small unit doses in the dosage form such as capsules, tablet, powders, liquid. It will not include any sterile preparation like injectables or eye drops.

4. Regulatory requirements of nutraceuticals in ASEAN (9-15)

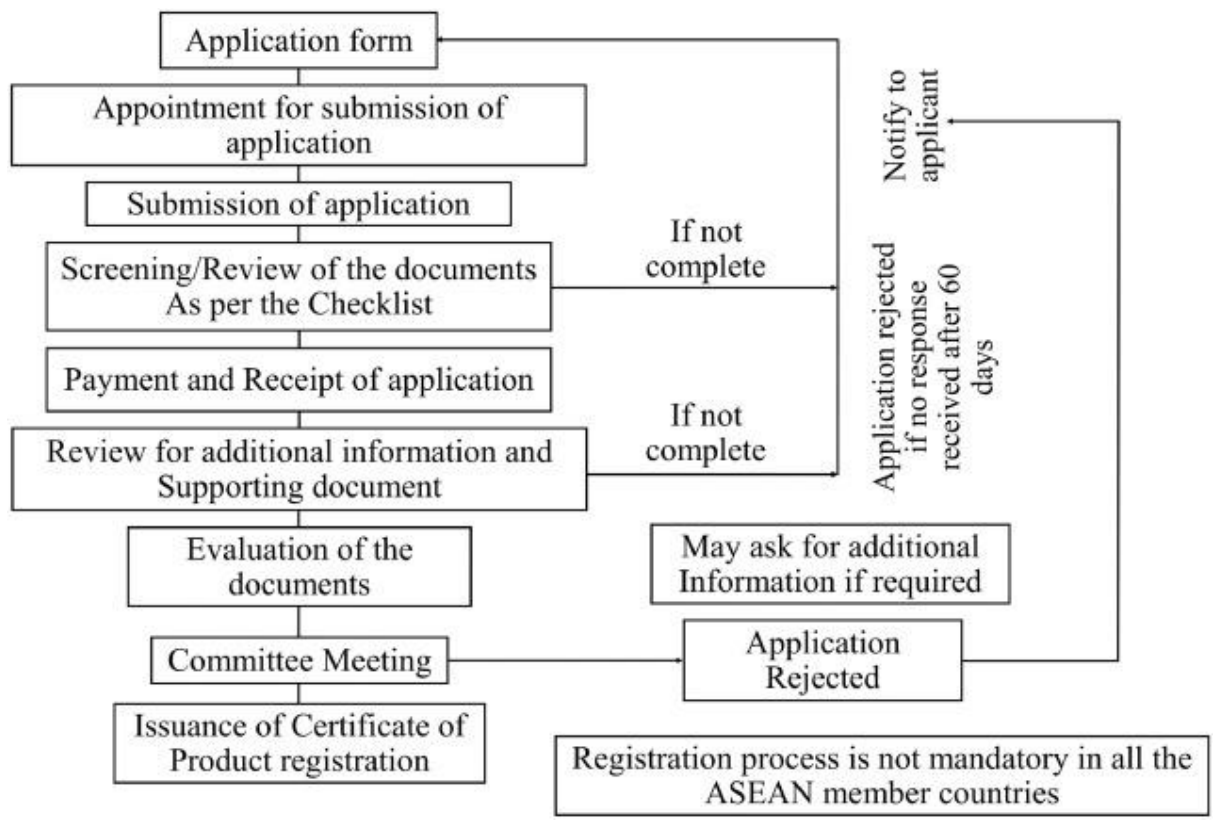

Figure 5. Flowchart for registration process in ASEAN 


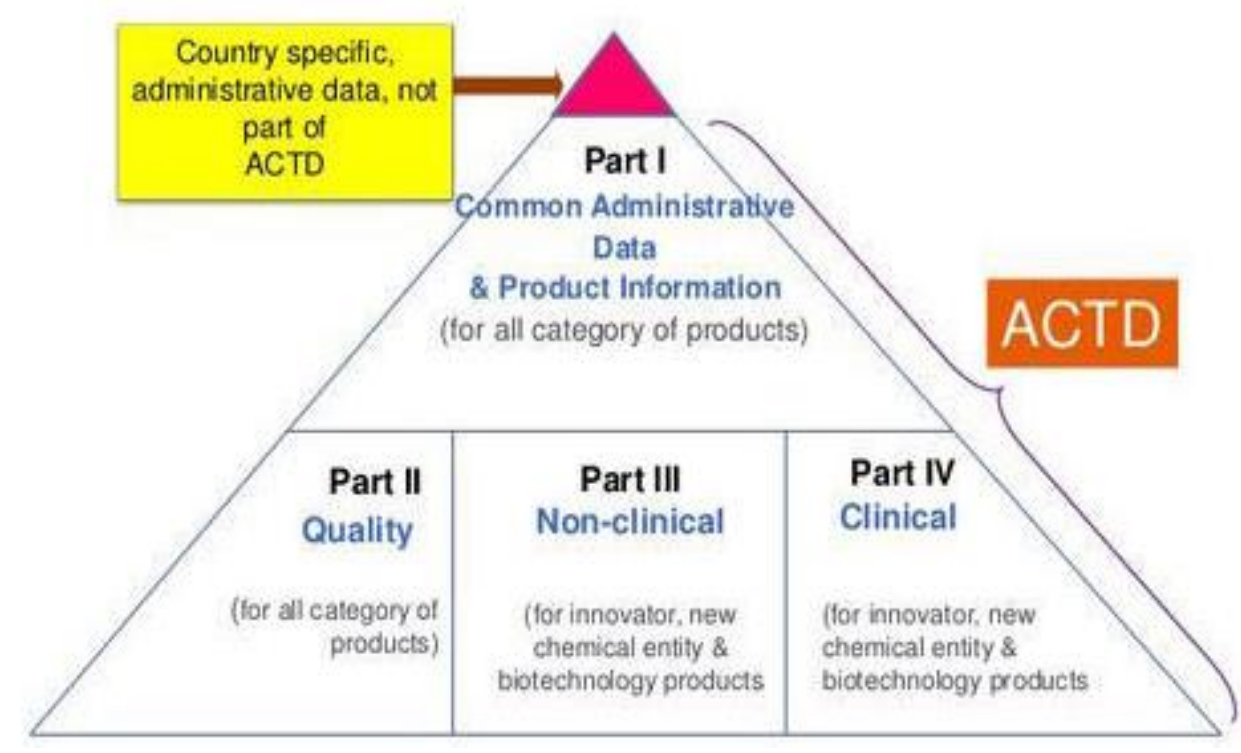

Figure 6. ASEAN Common Technical Dossier (ACTD)

ASEAN Common Technical Dossier (ACTD) is a guideline of the agreed upon common format for the preparation of an organized CTD application that will be registered to ASEAN regulatory authorities for the registration of pharmaceuticals intended for human use. ACTD guidelines will reduce the resources and time required to compile the registration application and will assist the arrangement of submission of electronic document.

The overall dossier is organized in following 4 parts-

Part I- Table of contents, Administrative data and Product information

Section A- Introduction

Section B- Overall ACTD table of contents

Section C- Documents required for registration (for example: application forms, labeling, product data sheet, prescribing information)

Part II- Quality document

Section A-Table of contents

Section B- Quality overall summary

Section C- Body of data

Part III- Nonclinical document

Section A- Table of content

Section B- Non clinical overview

Section C- Non clinical tabulated and written summaries
a) Table of Contents
b) Pharmacology
c) Pharmacokinetics
d) Toxicology

Section D- Non clinical study reports
a) Table of Contents
b) Pharmacology

c) Pharmacokinetics

d) Toxicology

Part IV-Clinical document

Section A- Table of Contents Section

Section B- Clinical Overview Section

Section C- Clinical Summary

a) Summary of Biopharmaceutics and Associated Analytical Methods

b) Summary of Clinical Pharmacology Studies

c) Summary of Clinical Efficacy

d) Summary of Clinical Safety

e) Synopses of Individual Studies

Section D- Tabular Listing of All Clinical Studies

Section E- Clinical Study Reports

Section F- List of Key Literature References

\section{Administrative Data requirements}

Common administrative data requirement that are essential for the registration of the nutraceuticals/health supplements in ASEAN countries are:-

- Application form.

- Manufacture license copy.

- Power of attorney.

- For manufacturing facility in the country, Good Manufacturing Process (GMP) certificate.

- Certificate of free sale issued in a country.

- Product information, must include drug interactions, usage indications, dosage, management of overdose, shelf life and storage conditions.

- Language to be inserted should be English along with regional language.

- Detailed manufacturing process along with In Process Quality Control (IPQC) procedure.

- Stability. 
- Quality and Safety specification.

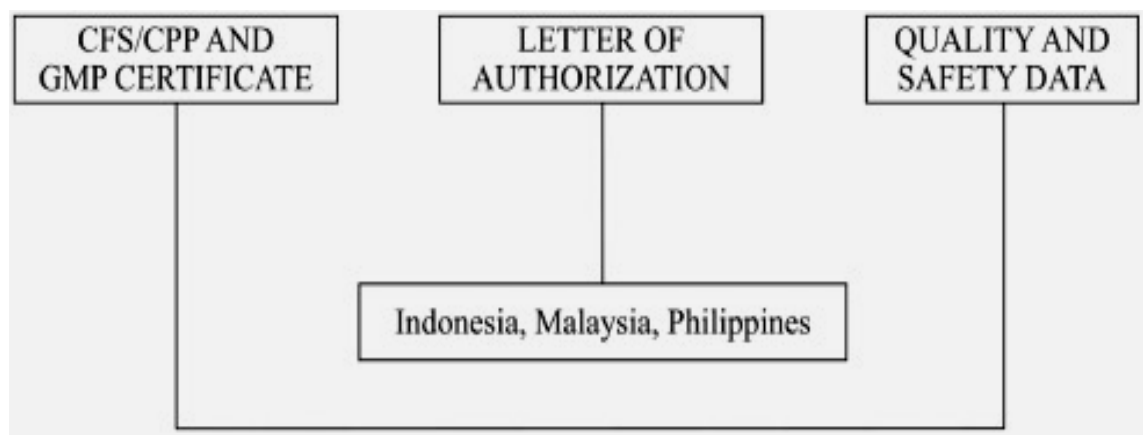

Cambodia, Indonesia, Malaysia, Philippines

Thailand, Vietnam
- Certificate of Analysis, active ingredients and excipients of 3 samples.

Figure 7. Administrative data requirement as per the countries in ASEAN

Table 1. Regulation of Governing body in ASEAN

\begin{tabular}{|c|c|c|}
\hline Country & Governing body & Regulation \\
\hline Indonesia & $\begin{array}{l}\text { National Agency of Drug and Food control } \\
\text { of Republic of Indonesia (NADFC) }\end{array}$ & $\begin{array}{l}\text { Food law no } 18 / 2012 \text { regulates all food and food } \\
\text { product that originates from biological source }\end{array}$ \\
\hline Philippines & Bureau of Food and Drugs (BFAD) & $\begin{array}{l}\text { As per administrative order no } 37 \mathrm{~s}, 1979 \text { food products } \\
\text { are registered with BFAD }\end{array}$ \\
\hline Vietnam & $\begin{array}{l}\text { Regulated by } 3 \text { different ministers- } \\
\text { Ministry of Health (MOH) } \\
\text { Ministry of Agriculture and Rural } \\
\text { Development (MARD) } \\
\text { Ministry of Industry and Trade (MOIT) }\end{array}$ & $\begin{array}{l}\text { Decree no } 38 / 2012 / \mathrm{NO}_{-} \mathrm{CP} \text { provides guidance to } \\
\text { MARD, MOIT, } \mathrm{MOH}\end{array}$ \\
\hline Myanmar & Myanmar Food and Drug Administration & Mandatory testing of food product before marketing \\
\hline Thailand & $\begin{array}{l}\text { Thai Food and Drug Administration of } \\
\text { Ministry of Public Health (MOPH) }\end{array}$ & $\begin{array}{l}\text { Food Act B.E. 2522(1979) controls import and export } \\
\text { of food products for sale }\end{array}$ \\
\hline $\begin{array}{l}\text { Brunei } \\
\text { Darussalam }\end{array}$ & $\begin{array}{l}\text { Brunei Darussalam Medicines Control } \\
\text { Authority (BDMCA) }\end{array}$ & $\begin{array}{l}\text { Do not require licensing or pre-market authorization } \\
\text { from BDMCA }\end{array}$ \\
\hline Cambodia & $\begin{array}{l}\text { Department of Drug and Food (DDF) under } \\
\text { Ministry of Health }\end{array}$ & $\begin{array}{l}\text { Safety, efficacy, quality of drug and efficacy of food } \\
\text { and cosmetic }\end{array}$ \\
\hline Malaysia & $\begin{array}{l}\text { Food Safety and Quality Division of } \\
\text { Ministry of Health Malaysia (FSQD) }\end{array}$ & $\begin{array}{l}\text { Mandatory registering the health supplements before } \\
\text { marketing }\end{array}$ \\
\hline Singapore & Singapore Food Agency (SFA) & $\begin{array}{l}\text { Health Supplements are not subjected to approval and } \\
\text { licensing by HAS for importation, manufacture and } \\
\text { sales }\end{array}$ \\
\hline
\end{tabular}

\section{Application form required for registration}

Table 2. Form requirements for registration process in ASEAN

\begin{tabular}{|c|c|}
\hline Form no & Document \\
\hline $03 \mathrm{~b}$ & $\begin{array}{l}\text { Form of Detailed written information of products for functional food, food fortified with } \\
\text { nutrients }\end{array}$ \\
\hline $03 \mathrm{c}$ & $\begin{array}{l}\text { Form of Detailed written information of products for tools, materials for packaging, food } \\
\text { containers }\end{array}$ \\
\hline 04 & Form of Plan of quality control \\
\hline 05 & $\begin{array}{l}\text { Form of Application for reissuance of Receipt of written publication of regulation conformity or written } \\
\text { certification of publication of conformity with food safety regulations }\end{array}$ \\
\hline 06 & Form of list of the facilities producing, trading food registering for export into Vietnam \\
\hline 07 & $\begin{array}{l}\text { Information on management system and capacity of controlling food safety of the competent } \\
\text { agencies of the exporting countries }\end{array}$ \\
\hline 08 & Summary of information on the conditions to ensure food safety of the producing, trading facilities \\
\hline
\end{tabular}

Table 3. List of health supplements to be registered in various countries

\begin{tabular}{l|l}
\hline $\begin{array}{c}\text { Health } \\
\text { Supplements }\end{array}$ & Countries \\
\hline Vitamin & Brunei Darussalam, Indonesia, Cambodia, Lao PDR, Malaysia, Philippines, Singapore, Thai, \\
\hline
\end{tabular}




\begin{tabular}{|l|l|}
\hline Mineral & $\begin{array}{l}\text { Vietnam } \\
\text { Brunei Darussalam, Indonesia, Cambodia, Lao PDR, Malaysia, Philippines, Singapore, Thai, } \\
\text { Vietnam, Myanmar }\end{array}$ \\
\hline Amino acid & $\begin{array}{l}\text { Brunei Darussalam, Cambodia, Indonesia, Lao PDR, Malaysia, Singapore, } \\
\text { Thailand }\end{array}$ \\
\hline Plants, Animals & $\begin{array}{l}\text { Brunei Darussalam, Cambodia, Indonesia, Lao PDR, Malaysia, Myanmar, } \\
\text { Singapore, Thailand, Vietnam }\end{array}$ \\
\hline Metabolites & Indonesia, Lao PDR, Thailand \\
\hline Enzymes & Brunei Darussalam, Cambodia, Indonesia, Lao PDR, Malaysia \\
\hline Concentrate & Brunei Darussalam, Indonesia, Malaysia, Thailand \\
\hline
\end{tabular}

Table 4. Contents claimed by the country

\begin{tabular}{|l|l|}
\hline \multicolumn{1}{|c|}{ Country } & \multicolumn{1}{c|}{ Contents claimed } \\
\hline Indonesia & $\begin{array}{l}\text { Five core nutrients (energy, fat, protein, CHO and sodium and nutrients. } \\
\text { Nutrients that are mandatory under specific requirements; energy from fat, saturated fat, trans } \\
\text { fat, cholesterol, dietary fiber sugar; vitamin A, vitamin C, calcium and iron. }\end{array}$ \\
\hline Malaysia & \begin{tabular}{l} 
Four core nutrients (energy, fat, protein and CHO). \\
\hline Philippines
\end{tabular} \\
\hline Fingapore & $\begin{array}{l}\text { Four core nutrients (energy, fat, protein and CHO). } \\
\text { Nutrients to be declared for fortificants of fortified food. }\end{array}$ \\
\hline Thailand & Four core nutrients (energy, fat, protein and CHO). \\
\hline & $\begin{array}{l}\text { Four core nutrients (energy, fat, protein and CHO), saturated fat, and cholesterol, dietary fiber, } \\
\text { sugar, sodium, vitamin A, B1, B2, calcium, iron and nutrients. } \\
\text { Simplified format includes the four core nutrients as well as sugar and sodium. }\end{array}$ \\
\hline
\end{tabular}

Table 5. Purpose for registration of health supplements in various countries

\begin{tabular}{|l|l|}
\hline \multicolumn{1}{|c|}{ Purpose } & \multicolumn{1}{c|}{ Registration required in countries } \\
\hline Support or maintain healthy function of body & Brunei Darussalam, Singapore \\
\hline Supplement normal diet & Cambodia, Lao PDR, Indonesia, Malaysia, Singapore \\
\hline Supplement or fortifying ordinary or usual diet & Philippines \\
\hline Enhance body function & Vietnam \\
\hline Improve and maintain healthy condition & Cambodia, Lao PDR \\
\hline Use for the patients under dietaru regimes & Cambodia \\
\hline Improve health & Thailand \\
\hline
\end{tabular}

\section{Timeline for Evaluation}

Table 6. Timeline for evaluation

\begin{tabular}{|l|l|}
\hline \multicolumn{1}{|c|}{ Country } & \multicolumn{1}{c}{ Timeline } \\
\hline Brunei Darussalam & NA \\
\hline Cambodia & $6-12$ months \\
\hline Lao PDR & NA \\
\hline Malaysia & 6 months \\
\hline Singapore & $2-3$ months \\
\hline Myanmar & NA \\
\hline Thailand & 6 months \\
\hline Indonesia & $2-3$ months \\
\hline Philippines & $2-3$ months \\
\hline Vietnam & $2-3$ months \\
\hline Pre-marketing Evaluation
\end{tabular}

\section{Pre-marketing Evaluation}

Table 7. Technical requirement of data in various countries

\begin{tabular}{l|l|}
\hline \multicolumn{1}{|c|}{ Content } & \multicolumn{1}{c}{ Applicable countries } \\
\hline GMP & Cambodia, Indonesia Malaysia, Philippines, Vietnam \\
\hline Formula & $\begin{array}{l}\text { Brunei Darussalam, Cambodia, Indonesia, Malaysia, Philippines, Thailand, } \\
\text { Vietnam }\end{array}$ \\
\hline Raw material specification & $\begin{array}{l}\text { Brunei Darussalam, Cambodia, Indonesia, Malaysia, Philippines, Thailand, } \\
\text { Vietnam }\end{array}$ \\
\hline Manufacturing process & Cambodia, Indonesia, Malaysia, Philippines, Thailand, Vietnam \\
\hline Finished product specification & Cambodia, Indonesia, Malaysia, Philippines, Thailand, Vietnam \\
\hline Stability study & Indonesia, Malaysia, Philippines, Vietnam \\
\hline Water content & Indonesia, Philippines \\
\hline
\end{tabular}


Disintegration time

Cambodia, Indonesia, Malaysia, Philippines, Vietnam

\section{Labeling requirements}

Table 8. Labeling data requirements of various countries

\begin{tabular}{|l|l|}
\hline \multicolumn{1}{|c|}{ Country } & \multicolumn{1}{|c|}{ Labeling requirements } \\
\hline Brunei Darussalam & $\begin{array}{l}\text { Product name, Composition, Dosage form, Administration and Doses, Packaged size, } \\
\text { Manufacturer name and Address, Registration number, Batch No, Side effects, } \\
\text { Contraindication, Precaution, Storage condition. }\end{array}$ \\
\hline Cambodia & $\begin{array}{l}\text { Product name, Composition, Dosage form, Administration and Doses, Packaged size, } \\
\text { Manufacturer name and Address, Batch No, Expiry, Side effects, Contraindication, } \\
\text { Precaution, Storage condition. }\end{array}$ \\
\hline Indonesia & $\begin{array}{l}\text { Product name, Composition, Dosage form, Administration and Doses, Packaged size, } \\
\text { Manufacturer name and Address, Distributor name and Address, Registration number, Batch } \\
\text { No, Expiry, Side effects, Contraindication, Precaution, Storage condition. }\end{array}$ \\
\hline Palaysia & $\begin{array}{l}\text { Product name, Composition, Dosage form, Administration and Doses, Packaged size, } \\
\text { Manufacturer name and Address, Registration number, Batch No, Expiry, Side effects, } \\
\text { Contraindication, Precaution, Storage condition. }\end{array}$ \\
\hline Thailand & $\begin{array}{l}\text { Product name, Composition, Dosage form, Administration and Doses, Packaged size, } \\
\text { Manufacturer name and Address, Distributor name and Address, Batch No, Expiry, Side } \\
\text { effects, Contraindication, Precaution, Storage condition. }\end{array}$ \\
\hline Vietnam & $\begin{array}{l}\text { Product name, Composition, Administration and Doses, Packaged size, Manufacturer name } \\
\text { and Address, Distributor name and Address, Registration number, Expiry, Contraindication, } \\
\text { Precaution, Storage condition. }\end{array}$ \\
\hline $\begin{array}{l}\text { Product name, Composition, Dosage form, Administration and Doses, Packaged size, } \\
\text { Manufacturer name and Address, Distributor name and Address, Registration number, Batch } \\
\text { No, Expiry, Side effects, Contraindication, Precaution, Storage condition. }\end{array}$
\end{tabular}

\section{Post-marketing control}

It includes:

I. Monitoring of labeling, packing and advertisement.

II. Sampling and label test.

III. Monitoring of adverse effects.

IV. Inspection of manufacturer and distributor.

V. Post marketing surveillance.

Table 9. Post marketing control

\begin{tabular}{|l|c|c|c|c|c|}
\hline \multicolumn{1}{|c|}{ Country } & $\begin{array}{c}\text { Monitoring of } \\
\text { labeling, packing } \\
\text { and advertisement }\end{array}$ & $\begin{array}{c}\text { Sampling } \\
\text { and label test }\end{array}$ & $\begin{array}{c}\text { Monitoring of } \\
\text { adverse effects }\end{array}$ & $\begin{array}{c}\text { Inspection of } \\
\text { manufacturer } \\
\text { and distributor }\end{array}$ & $\begin{array}{c}\text { Post marketing } \\
\text { surveillance }\end{array}$ \\
\hline Brunei Darussalam & - & $\mathrm{R}$ & - & $\mathrm{R}$ & $\mathrm{R}$ \\
\hline Cambodia & - & - & - & - & - \\
\hline Malaysia & $\mathrm{R}$ & $\mathrm{R}$ & $\mathrm{R}$ & $\mathrm{R}$ & $\mathrm{R}$ \\
\hline Singapore & $\mathrm{R}$ & $\mathrm{R}$ & $\mathrm{R}$ & $\mathrm{CPM}$ & $\mathrm{R}$ \\
\hline Lao PDR, Myanmar & - & - & - & - & - \\
\hline Thailand & $\mathrm{R}$ & - & $\mathrm{R}$ & $\mathrm{R}$ \\
\hline $\begin{array}{l}\text { Indonesia, } \\
\text { Philippines }\end{array}$ & $\mathrm{R}$ & $\mathrm{R}$ & $\mathrm{R}$ & $\mathrm{R}$ & $\mathrm{R}$ \\
\hline Vietnam & $\mathrm{R}$ & - & $\mathrm{R}$ & - & $\mathrm{R}$ \\
\hline
\end{tabular}

\section{Marketed nutraceuticals in ASEAN}

\begin{tabular}{|c|c|c|c|c|}
\hline Marketed Product & Brand name & Manufacturer & Category & Formulated to support \\
\hline$\frac{P Q \odot \%}{\text { Centrum }}$ & Centrum Silver & $\begin{array}{l}\text { Wyeth } \\
\text { Pharmaceutical }\end{array}$ & $\begin{array}{l}\text { Multivitamin } \\
\text { and } \\
\text { Multimineral }\end{array}$ & $\begin{array}{l}\text { Healthy heart } \\
\text { Good eyesight } \\
\text { Immunity } \\
\text { Strong bones and muscle } \\
\text { Healthy skin and nerves }\end{array}$ \\
\hline
\end{tabular}




\begin{tabular}{|c|c|c|c|c|}
\hline 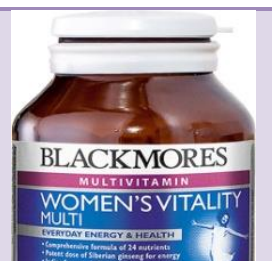 & $\begin{array}{l}\text { Blackmores } \\
\text { Women's } \\
\text { Vitality } \\
\text { Multivitamin }\end{array}$ & Blackmores & Multivitamin & $\begin{array}{l}\text { Body metabolism } \\
\text { Maintains healthy heart } \\
\text { Immune system } \\
\text { Reduces mental fatigue } \\
\text { Relieves tiredness } \\
\text { Reduces risk of cell damage }\end{array}$ \\
\hline & $\begin{array}{l}\text { Berocca } \\
\text { Orange } \\
\text { Vitamin } \\
\text { Effervescent }\end{array}$ & BAYER & $\begin{array}{l}\text { Vitamin and } \\
\text { Mineral }\end{array}$ & $\begin{array}{l}\text { Enhances mental and physical } \\
\text { performance } \\
\text { Improve alertness and } \\
\text { concentration power } \\
\text { Reduces tiredness }\end{array}$ \\
\hline & Enervon & UNILAB, INC & $\begin{array}{l}\text { Vitamin } \quad \text { B } \\
\text { Complex and } \\
\text { Vitamin C }\end{array}$ & $\begin{array}{l}\text { Helps promote increased energy } \\
\text { Enhance immunity system } \\
\text { Treatment of Vit B complex and } \\
\text { Vit C deficiencies }\end{array}$ \\
\hline 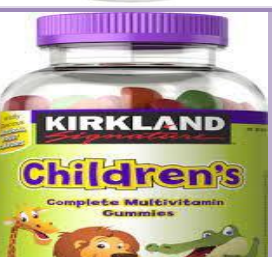 & $\begin{array}{l}\text { Kirkland } \\
\text { Signature } \\
\text { Children's } \\
\text { Complete } \\
\text { Multivitamin } \\
\text { Gummies }\end{array}$ & Kirkland & Multivitamin & $\begin{array}{l}\text { Enhances child immunity, brain } \\
\text { function and physical growth }\end{array}$ \\
\hline PIN & $\begin{array}{l}\text { Nordic natural } \\
\text { Pre Natal DHA } \\
\text { Multivitamin }\end{array}$ & Nordic Naturals & Multivitamin & $\begin{array}{l}\text { Natural omega-3s } \\
\text { Mood support } \\
\text { Prenatal DHA support } \\
\text { Brain development in babies } \\
\text { during pregnancy }\end{array}$ \\
\hline
\end{tabular}

\section{Conclusion}

Nutraceuticals have proven health benefits as well as their consumption will defend disease and also will allow mankind to maintain their overall good health. Health Professional, Regulatory Toxicologist and nutritionist should combine efforts and plan significant regulation which will impart the ultimate health. For this, it is required to execute a regulatory body, to standardize nutraceutical industry.

\section{Acknowledgements}

We would like to express our sincere gratitude to IJDRA Journal for publishing our article

Financial Disclosure statement: The author received no specific funding for this work.

\section{Conflict of Interest}

The authors declare that there is no conflict of interest regarding the publication of this article.

\section{References}

1. Das L, Bhaumik E, Raychauduri U, Chakraborty R. Role of Nutraceutials in Human Health. Journal of Food Science and Technology [Internet]. 2012 Apr [cited 2021 Nov 14]; 49(2):173-183. Available from:

https://www.ncbi.nlm.nih.gov/pmc/articles/PMC3550857/

2. Chauhan B, Kumar G, Kalam N, Ansari SH. Current concepts and prospects of herbal nutraceuticals: A Review. Journal of Advanced Pharmaceutical Technology and Research [Internet]. 2013 Jan [cited 2021 Nov 14]; 4(1):4-8. Available from:

https://www.ncbi.nlm.nih.gov/pmc/articles/PMC3645360/

3. Nasri H, Baradaran A, Shirzad h, Rafieian-Kopaei M. New concepts in nutraceuticals as alternative for pharmaceuticals. International Journal of Preventive Medicine [Internet]. 2014 Dec [cited 2021 Nov 14]; 12:1487-1499. Available from:

https://www.ncbi.nlm.nih.gov/pmc/articles/PMC4336979/ 
4. Singh M C, Gujar K N. Nutraceuticals: Uses, Risk and Regulatory Scenario. International Journal of Pharmacy and Pharmaceutical Sciences [Internet]. 2013 Jan [cited 2021 Nov 15]; 5:23-26. Available from:

https://www.researchgate.net/publication/288426967_Nut raceuticals_Uses_risks_and_regulatory_scenario

5. Alicia $\mathrm{AG} \mathrm{Ng}$, MJ. ASEAN harmonization of technical standards on health supplements- An industry perspective. Regulatory Focus [Internet]. 2021 Jun [cited 2021 Nov 14]; 1-15. Available from: https://www.raps.org/news-and-articles/newsarticles/2021/6/journey-of-the-asean-harmonization-oftechnical-st

6. Wai Mun Poon. ASEAN harmonized standards and requirements for health supplements [Internet]. $2021 \mathrm{Jan}$ [cited 2021 Nov 14]; 1-5. Available from: https://www.vitafoodsinsights.com/regulation/aseanharmonised-standards-and-requirementshealthsupplements.

7. Health supplements and nutraceuticals compliance guidance. International Alliance of Dietary/Food Supplement Association [Internet]. 2018 Jan [cited 2021 Nov 14]; 1.0:1-60. Available from: https://rechan.in/pdf/Compliance_Document.PDF

8. Athalya M, Vaghela S, Bhavsar N. Study of the Registration Guideline of Nutraceutical Product in ASEAN countries. Applied Clinical Research, Clinical Trials and Regulatory Affairs [Internet]. 2020 [cited 2021 Nov 14]; 7:1-13. Available from: https://www.researchgate.net/publication/335862998_The _Study_of_the_Registration_Guideline_of_Nutraceutical_ Products_in_ASEAN_Countries

9. The ASEAN Common Technical Dossier (ACTD) for the Registration of Pharmaceuticals for Human Use. Organization of the Dossier [Internet]. 2007 [cited 2021 Nov 15]; 1-3. Available from: https://www.hsa.gov.sg/docs/defaultsource/hprg/therapeutic-products/guidancedocuments/actd_organizationofdossier.pdf\#: :text=This\% 20ASEAN\%20Common\%20Technical\%20Dossier,of\%20 pharmaceuticals\%20for\%20human\%20use.

10. ASEAN Common Technical Dossier (ACTD). The ASEAN Secretariat Jakarta [Internet]. 2016 [cited 2021 Nov 16]; 1-198. Available from: https://www.fda.gov.ph/wpcontent/uploads/2021/03/ASEAN-Common-TechnicalDossier-ACTD-December-2016-from-ASEANSecretariat.pdf

11. ACTD Dossier. Pharma ACTD Dossiers Professionals [Internet]. [cited 2021 Nov 16]. Available from: https://www.pharmaactddossiers.com/actd-dossiers/

12. ANNEX IX ASEAN Guidelines on Labeling Requirements for Health Supplements [Internet]. 2015 Oct [cited 2021 Nov 15]; 1.0;1-14. Available from: https://asean.org/wp-content/uploads/2017/09/ASEANGuidelines-on-Labelling-Req.-for-HS-2-Oct-2015-revwith-discla....pdf

13. Tripathi C, Girme A, Champaneri S, Patel R, Hingorani L. Nutraceutical Regulations: An opportunity in ASEAN countries. Nutrition [Internet]. 2020 Jan [cited 2021 Nov 15]; 74(1):1-15. Available from:

https://www.researchgate.net/publication/338671449_Nut raceutical_Regulations_An_Opportunities_in_ASEAN_C ountries

14. Dwyer J, Coates P, Smith M. Dietary Supplements: Regulatory Challenges and Research Resources. Nutrients [Internet]. 2018 Jan [cited 2021 Nov 15]; 10(1);1-24. Available from:

https://www.ncbi.nlm.nih.gov/pmc/articles/PMC5793269/ 